\title{
Medial mini-open versus percutaneous pin fixation for type III supracondylar fractures in children
}

\author{
Ersin Erçin, M.D., ${ }^{1}$ Mustafa Gökhan Bilgili, M.D.,, ${ }^{1}$ Emre Baca, M.D., ${ }^{1}$ Serdar Hakan Başaran, M.D., ${ }^{2}$ \\ Alkan Bayrak, M.D., ${ }^{1}$ Cemal Kural, M.D., ${ }^{1}$ Mustafa Cevdet Avkan, M.D. ${ }^{1}$
}

${ }^{1}$ Department of Orthopaedics and Traumatology, Bakırköy Dr. Sadi Konuk Training and Research Hospital, İstanbul-Turkey

${ }^{2}$ Department of Orthopaedics and Traumatology, Karabük University Faculty of Medicine, Zonguldak-Turkey

\begin{abstract}
BACKGROUND: The present objective was to compare medial mini-open and percutaneous treatment of pediatric supracondylar fractures according to fluoroscopy time, duration of surgery, and iatrogenic ulnar nerve injury.

METHODS: A total of 104 Gartland type III supracondylar humerus fractures were prospectively evaluated between $20 \mathrm{II}$ and $20 \mathrm{I} 3$. Patients were divided into 2 groups according to type of fixation. In Group A (4I patients), medial pin was inserted with mini-open incision with 2 lateral pins inserted percutaneously. In Group B (63 patients), all pins were inserted percutaneously. Mean follow-up

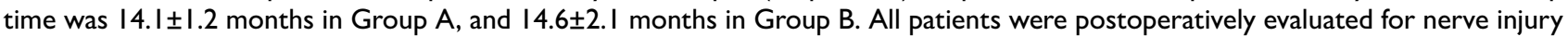
with both motor and sensory function assessment. Length of surgery, total fluoroscopy time, fluoroscopy time for medial pin insertion, Baumann's angle, humeral capitellum angle, final carrying angle, and range of motion were recorded.
\end{abstract}

RESULTS: Sensorial evaluation showed that Group A had 3 poor, and I fair results, and Group B had 2 poor, and I fair results. No statistically significant differences were observed, including no differences in either surgery or total fluoroscopy times between groups. However, fluoroscopy time during medial pin placement was significantly lower in the mini-open group.

CONCLUSION: In conclusion, similar results of both techniques were observed, and both carry risk of iatrogenic ulnar nerve injury. Medial pin placement is easier and less demanding when used with mini-open technique.

Keywords: Fracture; humerus; pediatric; supracondylar fracture; ulnar nerve.

\section{INTRODUCTION}

Supracondylar humerus fractures are those most likely to require surgery in children. ${ }^{[1,2]}$ Closed reduction and percutaneous pin fixation are the current treatment modalities. The primary disadvantages of the percutaneous technique are ulnar nerve injury and prolonged use of fluoroscopy. ${ }^{[3]}$ In the literature, incidence of ulnar nerve palsy ranges from $0-14.3 \%$ after closed pinning. ${ }^{[4-8]}$ Due to this risk, some authors advocate only lateral pin placement, while others advo-

\footnotetext{
This study presented in part as an oral presentation of free paper at the $17^{\text {th }}$ European Federation of National Associations of Orthopaedics and Traumatology Congress (Geneva, Switzerland, June 0I-03, 2016).

Address for correspondence: Ersin Erçin, M.D.

Bakırköy Dr. Sadi Konuk Eğitim ve Araştırma Hastanesi,

Ortopedi ve Travmatoloji Kliniği, İstanbul, Turkey

Tel: +90 212 - 4142332 E-mail: ersine@hotmail.com

Qucik Response Code Ulus Travma Acil Cerrahi Derg

$\begin{array}{ll}\text { 口ity } & \text { 2016;22(4):350-354 } \\ \text { doi: } 10.5505 / \text { tjtes.2015.20268 }\end{array}$

Copyright 2016

TJTES
}

cate medial mini-open technique. ${ }^{[9,10]}$ However, whether miniopen approach is necessary to avoid iatrogenic ulnar nerve injury has yet to clarified.

Fluoroscopy usage is essential for closed reduction and percutaneous K-wire fixation of supracondylar fractures, yet few studies have addressed radiation exposure in displaced supracondylar humeral fractures. In a recent study, authors concluded that surgeons were exposed to direct radiation beam a median of $13 \%$ of surgery duration. ${ }^{[1]}$ The present objective was to compare medial mini-open and percutaneous treatments of pediatric supracondylar fractures by fluoroscopy time, surgery duration, and occurrence of iatrogenic ulnar nerve injury.

\section{MATERIALS AND METHODS}

A total of I32 Gartland type III supracondylar humerus fractures were treated with closed reduction and crossed $\mathrm{K}$-wire fixation between $201 \mathrm{I}$ and 2013. Informed consent was obtained from patients and from the ethics committee.

Inclusion criteria were patients with Gartland type III frac- 
tures who had 2 lateral and I medial pins placed during surgery. Patients with preoperative neurovascular injuries, open fractures, previous ipsilateral elbow fractures, or flexion fractures were excluded. Specifically, 3 patients with flexion fractures, 3 with open fractures, 4 with preoperative nerve paralysis (2 median, I ulnar, I radial nerve), I who had undergone previous surgery for olecranon fracture, 2 who did not attend final examination, and 15 patients who had undergone only I lateral and medial pin fixation were excluded from the study.

A total of 104 patients were included. Patients were divided into 2 groups according to type of fixation: medial mini-open (Group A) and percutaneous (Group B). Four attending physicians treated the patients, while residents under the supervision of an attending physician performed some surgical procedures. Children were randomized based on which orthopedic surgeon was on trauma call: 2 surgeons (M.G.B., E.E.) used medial mini-open technique (on patients in Group A), while the others (E.B., S.H.B.) used percutaneous technique, (on patients in Group B). The same pin configurationlateral divergent 2 pins and I crossed medial pin- was used. All patients underwent surgery under general anesthesia with closed reduction by fluoroscopic control in supine position.

In Group A (4I patients), I pin was inserted percutaneously from the lateral aspect of the elbow across the lateral cortex to the medial cortex, with the elbow in hyperflexion, before a small medial incision of $\mathrm{I}-\mathrm{I} .5 \mathrm{~cm}$ was made over the medial epicondyle. Superficial dissection was performed to ensure that the pin had been placed in the medial epicondyle and that the ulnar nerve was not anteriorly subluxated over the medial epicondyle. The medial pin was then placed in extended arm position, starting from the medial epicondyle to the lateral cortex. Then, another lateral pin was inserted percutaneously across the lateral cortex to the medial cortex. In Group B (63 patients), all pins were inserted percutaneously from the lateral side with the same order.

During surgery, total fluoroscopy time and fluoroscopy time for medial pin insertion were measured. After fixation of the fracture, pins bended outside the skin, and posterior long-arm splints were applied in the neutral position. Pins were removed after 3-4 weeks. All patients were clinically and radiologically evaluated at I week, 4 weeks, 3 months, and 6 months. Evaluation consisted of assessment of the carrying angle, measurement of range of motion of the elbow, and neurologic examination. All patients were evaluated for nerve injury with both motor and sensory function assessments. Sensory assessments were made by Semmes-Weinstein monofilament test and static 2-point discrimination test. Monofilament 2.83 was considered normal, and in static 2-point discrimination, $<6 \mathrm{~mm}$ was considered normal, 6-10 mm was considered fair, and $10-15 \mathrm{~mm}$ was considered poor. ${ }^{[12]}$

In radiographic evaluation, anteroposterior and lateral radiography of the elbow was assessed by 2 researchers (E.E. and

Table I. Patients data

\begin{tabular}{|c|c|c|c|}
\hline & Medial mini-open incision & All percutaneous group & $\mathbf{p}$ \\
\hline No. of patients & 41 & 63 & \\
\hline Age (year) & $6.2 \pm 2.65$ & $6.67 \pm 3.11$ & 0.425 \\
\hline Sex & & 0.946 & \\
\hline Male & 25 & 38 & \\
\hline Female & 16 & 25 & \\
\hline Side & & & 0.082 \\
\hline Right & 14 & 12 & \\
\hline Left & 27 & 51 & \\
\hline Mono Filament & & & 0.593 \\
\hline Normal & 37 & 60 & \\
\hline Fair & I & 1 & \\
\hline Poor & 3 & 2 & \\
\hline Time from trauma to surgery (hour) & $17.15 \pm 6.67$ & $15.1 \pm 6.77$ & 0.132 \\
\hline Fluoroscopy time for medial pin (second) & $8.85 \pm 3.07$ & $10.52 \pm 3.39$ & 0.012 \\
\hline Fluoroscopy time for lateral pin (second) & $32.76 \pm 6.07$ & $30.94 \pm 6.85$ & 0.01 \\
\hline Total fluoroscopy time (second) & $41.61 \pm 9.25$ & $41.46 \pm 10.03$ & 0.939 \\
\hline Anesthesia time (minutes) & $47.7 I \pm 14.44$ & $53.56 \pm 21.83$ & 0.134 \\
\hline Hospitalization time (day) & $2.2 \pm 1.12$ & $1.98 \pm 1.29$ & 0.393 \\
\hline Pin removal time (day) & $30.8 \pm 5.93$ & $30.33 \pm 5.74$ & 0.687 \\
\hline
\end{tabular}


M.G.B.). Baumann angle was measured on the anteroposterior radiograph of the elbow at 3-month follow-up. Humerocapitellar angle was measured at the lateral elbow radiograph. Single-measure intraclass correlation coefficient was used for continuous variables, while Cohen kappa coefficient was used for categorical variables. Good interobserver agreement (0.6-0.8) was found for all continuous variables, and almost perfect agreement $(>0.8)$ was found for all categorical variables. Carrying angle was measured by full-circle goniometer and compared with the contralateral arm.

NCSS statistics software (2007; NCSS, LLC., Kaysville, Utah, USA) was used for statistical analysis. Statistical comparisons among groups were made with the Mann-Whitney U-test, Pearson's chi-squared test, and independent samples t-test. A $P$ value $<0.05$ was accepted as significant.

\section{RESULTS}

Demographic characteristics and surgical properties are shown in Table I. No significant differences were found $(p>0.05)$ between groups regarding Baumann angle, humerocapitellar angle, carrying angle, elbow extension, or elbow flexion. Patients were compared according to hospitalization time, pin removal, C-arm time for medial pin placement, total fluoroscopy time, and anesthesia time. Hospitalization time, pin removal time, total fluoroscopy time, and anesthesia time showed no significant difference. However, fluoroscopy time for medial pin placement was significantly shorter in Group A $(p=0.012)$, while lateral pin placement time was significantly shorter in Group B $(p=0.01)$ (Table I).

All patients had normal motor function at postoperative firstweek control. According to monofilament test, all patients had normal, 2.83 results. However, on static 2-point discrimination test, Group A included 3 poor, and I fair results, while Group B included 2 poor, and I fair results ( $<6 \mathrm{~mm}$ was considered normal, 6-10 mm was considered fair, $10-15 \mathrm{~mm}$ was considered poor). No significant difference was found, regarding these results. $(p=0.593)$. All patients had complete return of nerve function and full movement of the elbow at 6-month follow-up. No alteration was made to treatment of patients with poor or fair results; no reduction loss was observed during follow-up. All incisions in the mini-open group healed without complication.

Pin site infection occurred in 2 (4.9\%) patients in Group A, and $3(4.8 \%)$ patients in Group B. Oral antibiotics were used in all cases. No significant difference in occurrence of infection was observed between groups $(p>0.05)$. No deep infection or osteomyelitis occurred.

\section{DISCUSSION}

Surgical treatment of displaced supracondylar humeral fractures consists of open or closed reduction with K-wire fixation. Closed reduction and percutaneous fixation with crossed K-wires shows successful results. However, debate persists regarding optimal pin fixation technique. Biomechanical studies suggest that medial and lateral crossed K-wire fixation is the most stable. ${ }^{[13,14]}$ Some authors assert the importance of an additional medial K-wire to prevent reduction loss. ${ }^{[15,16]}$

Incidence of iatrogenic nerve injury of $14.3 \%$ was recently reported in surgically treated cases of supracondylar humerus fracture. In the same study, the ulnar nerve was reported as that most commonly injured $(82.1 \%)$, followed by the radial $(7.7 \%)$ and median $(5.1 \%)$ nerves. ${ }^{[5]}$ In a randomized prospective study, the ulnar nerve was injured in 3 of 557 (0.53\%) cases with laterally introduced pins. Medially introduced pins resulted in ulnar nerve injury in 49 of $808(6 \%)$ cases. The same authors found a $21 \%$ rate of reduction loss in cases of laterally placed pins. Medial and lateral pin placement had a significantly lower reduction loss rate of $4 \%{ }^{[10]}$

In spite of biomechanical advantages to medial and lateral crossed wire fixation, ulnar nerve injury is a potential complication of medial pin placement. In order to reduce the risk of ulnar nerve palsy, several precautions are suggested, including making a small incision over the medial epicondyle for direct visualization. ${ }^{[17]}$ However, it is not clear whether a mini-incision technique can prevent iatrogenic ulnar nerve injury. Although visualizing the ulnar nerve via a small incision prior to pin placement is theoretically less risky, ulnar nerve lesions are usually caused by the prevention of normal anterior translation to the ulnar nerve, rather than penetrations of the nerve. ${ }^{\left[{ }^{18]}\right.}$ In 2 studies in which lateral-pin and crossedpin medial mini-open techniques were compared, no iatrogenic ulnar nerve injury was reported in either group. Both techniques were determined to be effective for treatment of supracondylar humerus fractures. ${ }^{[10,19]}$

In a meta-analysis of randomized controlled trials, crossedpinning fixation was determined to carry greater risk of iatrogenic ulnar nerve injury than lateral pinning, and the later technique was recommended. ${ }^{[20]}$ In a single retrospective cohort study that included 65 patients (29 Gartland type III and 36 Gartland type II fractures), authors reported I iatrogenic ulnar nerve injury and recommended crossed-pin fixation with mini-open technique as a safe and reliable method. [4] The present is the first study to compare medial mini-open crossed-pinning and percutaneous crossed-pinning techniques. No significant difference in incidence of ulnar nerve injury was found between the techniques $(p=0.593)$.

Initial neurovascular examination is vital in determining whether injury is the result of fracture displacement or surgical complication. The importance of preoperative neurologic examination was emphasized in a recent study, as was the potential for preoperative neurologic deficit to be missed in initial management. ${ }^{[21]}$ 
Ulnar nerve injury results in numbness of the little finger and the ulnar half of the ring finger. Sensory disturbance can be evaluated with threshold tests (such as the monofilament test). Alterations in sensory conduction are more sensitive indicators of nerve injury and found to correlate more directly with physical examination findings. ${ }^{[22]}$ In the present patients, monofilament test was conducted at I postoperative week. Group A had 3 poor and I fair results, while Group B had 2 poor and I fair results. No significant difference was observed. No patient had neurologic deficit in hand movement on physical examination. All sensory deficits were resolved at 6-month follow-up.

While fluoroscopy usage is essential, radiation exposure is a risk. ${ }^{[23,24]}$ Few reports have addressed fluoroscopy time of supracondylar humeral fracture surgery. In a study comparing open reduction and internal fixation with closed reduction and internal fixation in Gartland type III supracondylar fractures, surgery and fluoroscopy times were significantly longer in the closed reduction and fixation group. ${ }^{[3]}$ In another study of supracondylar humerus fractures, fluoroscopy time increased when closed reduction was intraoperatively switched to open reduction. The authors suggested that radiation exposure time be a factor when selecting surgical approach in prolonged closed reduction surgeries. ${ }^{[25]}$ The present surgery and fluoroscopy times were consistent with others reported. [3,25] In theory, open incision should have additional risk of morbidity, though there is no evidence that medial incision in mini-open technique causes additional healing problems. This may be due to the small incision size and minimal dissection required. No differences in healing were presently observed between the groups.

No significant difference in surgery or fluoroscopy times were observed between groups. However, fluoroscopy usage during medial pinning was significantly lower in the mini-open group. This may be due to clearer identification of medial epicondyle and easier pin placement, without ulnar nerve concern.

Small population size and short follow-up period were the present limitations, in addition to the method of randomization used. Although a randomized clinical trial would be ideal, an extremely large study group would be needed to assess iatrogenic ulnar nerve injury. It was concluded in a systematic review that a minimum of 1000 patients would be needed to determine difference in complication rates $(\alpha=0.05, \beta=0.8$, difference to detect $=0.035) .{ }^{[16]} \mathrm{It}$ was concluded in another review that a sample size of 2000 patients would be needed according to $1.6 \%$ difference $(\alpha=0.05$, $\beta=0.20$, power $=80 \%$ ) in cases of iatrogenic ulnar nerve injury, and the difficulties inherent in conducting such an investigation were emphasized. ${ }^{26]}$

Given the near impossibility of conducting such large prospective randomized studies, surgeon-randomized trials retain their value in the comparison of surgical treatment methods of supracondylar humerus fractures. ${ }^{[27-29]}$ In surgeon randomization, there is the risk that the surgeon may choose the mini-open technique if unable to palpate the ulnar nerve due to swelling. Rates of iatrogenic ulnar nerve injury would have been higher if the percutaneous technique had also been used in this group of patients.

The present study was the first to evaluate neurologic deficiency with monofilament test after surgical treatment of supracondylar humerus fractures. Similar surgery times show that the mini-open technique does not increase surgery time. All fractures united without radiological or clinical complications after 6 postoperative months. Ulnar nerve injury occurred in 7.3\% of Group A patients, and in 3.2\% of those in Group B. That this difference was not statistically significant may be due to palpation of the ulnar nerve during protection attempts.

In conclusion, medial mini-open technique had similar results to percutaneous technique; both carry the risk of iatrogenic ulnar nerve injury. Medial pin placement without injury is still a challenge in pediatric supracondylar humerus fracture surgery. Aside from the additional morbidity risk of mini-open incision, medial pin placement is easier and less demanding in mini-open technique.

\section{Compliance With Ethical Requirements}

The authors declare that they have no conflict of interest. All procedures performed in studies involving human participants were in accordance with the ethical standards of the institutional and/or national research committee and with the 1964 Helsinki Declaration and its later amendments or comparable ethical standards. Informed consent was obtained from all individual participants included in the study. Local institutional review board approval was also obtained.

\section{Conflict of interest: None declared.}

\section{REFERENCES}

1. Carson S, Woolridge DP, Colletti J, Kilgore K. Pediatric upper extremity injuries. Pediatr Clin North Am 2006;53:41-67. Crossref

2. Omid R, Choi PD, Skaggs DL. Supracondylar humeral fractures in children. J Bone Joint Surg Am 2008;90:1121-32. Crossref

3. Esen E, Doğramaci Y, Gültekin S, Görmeli G, Yildirim A, Kanatli U, et al. Comparison of radiation exposure times in the treatment of pediatric supracondylar humeral fractures with open-closed reduction and internal fixation. [Article in Turkish] Acta Orthop Traumatol Turc 2009;43:400-5.

4. Gordon JE, Patton CM, Luhmann SJ, Bassett GS, Schoenecker PL. Fracture stability after pinning of displaced supracondylar distal humerus fractures in children. J Pediatr Orthop 2001;21:313-8. Crossref

5. Khademolhosseini M, Abd Rashid AH, Ibrahim S. Nerve injuries in supracondylar fractures of the humerus in children: is nerve exploration indicated? J Pediatr Orthop B 2013;22:123-6. Crossref

6. Kumar R, Kiran EK, Malhotra R, Bhan S. Surgical management of the severely displaced supracondylar fracture of the humerus in children. Injury 2002;33:517-22. Crossref

7. Mostafavi HR, Spero C. Crossed pin fixation of displaced supracondylar humerus fractures in children. Clin Orthop 2000;376:56-61. Crossref 
8. Shim JS, Lee YS. Treatment of completely displaced supracondylar fracture of the humerus in children by cross-fixation with three Kirschner wires. J Pediatr Orthop 2002;22:12-6. Crossref

9. Skaggs DL, Hale JM, Bassett J, Kaminsky C, Kay RM, Tolo VT. Operative treatment of supracondylar fractures of the humerus in children. The consequences of pin placement. J Bone Joint Surg Am 2001;83-A:73540 .

10. Kocher MS, Kasser JR, Waters PM, Bae D, Snyder BD, Hresko MT, et al. Lateral entry compared with medial and lateral entry pin fixation for completely displaced supracondylar humeral fractures in children. A randomized clinical trial. J Bone Joint Surg Am 2007;89:706-12. Crossref

11. Eismann EA, Wall EJ, Thomas EC, Little MA. Direct beam radiation exposure to surgeons during pinning of supracondylar humerus fractures: does $\mathrm{C}$-arm position and the attending surgeon matter? J Pediatr Orthop 2014;34:166-71. Crossref

12. Lundborg G, Rosén B. The two-point discrimination test--time for a reappraisal? J Hand Surg Br 2004;29:418-22. Crossref

13. Pretell-Mazzini J, Rodriguez-Martin J, Andres-Esteban EM. Does open reduction and pinning affect outcome in severely displaced supracondylar humeral fractures in children? A systematic review. Strategies Trauma Limb Reconstr 2010;5:57-64. Crossref

14. Zamzam MM, Bakarman KA. Treatment of displaced supracondylar humeral fractures among children: crossed versus lateral pinning. Injury 2009;40:625-30. Crossref

15. Pretell-Mazzini J, Rodriguez-Martin J, Auñon-Martin I, Zafra-Jimenez JA. Controversial topics in the management of displaced supracondylar humerus fractures in children. Strategies Trauma Limb Reconstr 2011;6:43-50. Crossref

16. Slobogean BL, Jackman H, Tennant S, Slobogean GP, Mulpuri K. Iatrogenic ulnar nerve injury after the surgical treatment of displaced supracondylar fractures of the humerus: number needed to harm, a systematic review. J Pediatr Orthop 2010;30:430-6. Crossref

17. Brown IC, Zinar DM. Traumatic and iatrogenic neurological complications after supracondylar humerus fractures in children.J Pediatr Orthop 1995; 15:440-3. Crossref

18. Lee SS, Mahar AT, Miesen D, Newton PO. Displaced pediatric supracondylar humerus fractures: biomechanical analysis of percutaneous pinning techniques. J Pediatr Orthop 2002;22:440-3. Crossref
19. Maity A, Saha D, Roy DS. A prospective randomised, controlled clinical trial comparing medial and lateral entry pinning with lateral entry pinning for percutaneous fixation of displaced extension type supracondylar fractures of the humerus in children. J Orthop Surg Res 2012;7:6.

20. Zhao JG, Wang J, Zhang P. Is lateral pin fixation for displaced supracondylar fractures of the humerus better than crossed pins in children? Clin Orthop Relat Res 2013;471:2942-53. Crossref

21. Joiner ER, Skaggs DL, Arkader A, Andras LM, Lightdale-Miric NR, Pace JL, et al. Iatrogenic nerve injuries in the treatment of supracondylar humerus fractures: are we really just missing nerve injuries on preoperative examination? J Pediatr Orthop 2014;34:388-92. Crossref

22. Shin R, Ring D. The ulnar nerve in elbow trauma. J Bone Joint Surg Am 2007;89:1108-16. Crossref

23. Bahari S, Morris S, Broe D, Taylor C, Lenehan B, McElwain J. Radiation exposure of the hands and thyroid gland during percutaneous wiring of wrist and hand procedures. Acta Orthop Belg 2006;72:194-8.

24. Perisinakis K, Damilakis J, Theocharopoulos N, Papadokostakis G, Hadjipavlou A, Gourtsoyiannis N. Patient effective dose and radiogenic risks from fluoroscopically assisted surgical reconstruction of femoral fractures. Radiat Prot Dosimetry 2004;108:65-72. Crossref

25. Kraus R, Joeris A, Castellani C, Weinberg A, Slongo T, Schnettler $\mathrm{R}$. Intraoperative radiation exposure in displaced supracondylar humeral fractures: a comparison of surgical methods. J Pediatr Orthop B 2007;16:44-7. Crossref

26. Brauer CA, Lee BM, Bae DS, Waters PM, Kocher MS. A systematic review of medial and lateral entry pinning versus lateral entry pinning for supracondylar fractures of the humerus. J Pediatr Orthop 2007;27:181-6.

27. Kwak-Lee J, Kim R, Ebramzadeh E, Silva M. Is medial pin use safe for treating pediatric supracondylar humerus fractures? J Orthop Trauma 2014;28:216-21. Crossref

28. Tripuraneni KR, Bosch PP, Schwend RM, Yaste JJ. Prospective, surgeon-randomized evaluation of crossed pins versus lateral pins for unstable supracondylar humerus fractures in children. J Pediatr Orthop B 2009;18:93-8. Crossref

29. Gaston RG, Cates TB, Devito D, Schmitz M, Schrader T, Busch M, et al. Medial and lateral pin versus lateral-entry pin fixation for Type 3 supracondylar fractures in children: a prospective, surgeon-randomized study. $\mathrm{J}$ Pediatr Orthop 2010;30:799-806. Crossref

\section{ORİJINAL ÇALIŞMA - ÖZET}

\section{Çocuk tip III suprakondiler humerus kırıklarında medial mini açık teknikle perkütan tekniğin karşılaştırlması \\ Dr. Ersin Erçin, ${ }^{1}$ Dr. Mustafa Gökhan Bilgili, ${ }^{1}$ Dr. Emre Baca, ${ }^{1}$ Dr. Serdar Hakan Başaran, ${ }^{2}$ Dr. Alkan Bayrak, ${ }^{1}$ Dr. Cemal Kural, ${ }^{1}$ Dr. Mustafa Cevdet Avkan ${ }^{1}$}

${ }^{1}$ Bakırköy Dr. Sadi Konuk Eğitim ve Araştırma Hastanesi, Ortopedi ve Travmatoloji Kliniği, İstanbul ${ }^{2}$ Karabük Üniversitesi Tıp Fakültesi, Ortopedi ve Travmatoloji Kliniği, Zonguldak

AMAÇ: Bu çalışmada, çocukluk çağında görülen suprakondiler humerus kırıklarında medial mini açık teknikle perkütan tekniği karşısaştırıldı, floroskopi zamanı, cerrahi süre ve iyatrojenik ulnar sinir hasarı araştıııldı.

GEREÇ VE YÖNTEM: 201 I ve 2013 yılları arasında ameliyat edilen 104 adet Gartland tip III suprakondiler humerus kırığı ileriye yönelik olarak incelendi. Birinci gruptaki (Grup A) 4 I hastaya medial mini açık insizyonla medialden bir ve lateralden iki adet pin ile fiksasyonu yapıldı. İkinci gruptaki

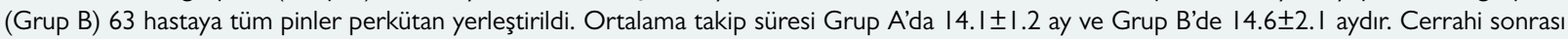
hastalar sinir yaralanması açısından motor ve duyu muayeneleri yapıldı. Cerrahinin süresi, toplam floroskopi süresi, medial pin için floroskopi süresi, Baumann açısı, humerokapitallar açı, son taşıma açııı ve eklem hareket açıklı̆̆ değerlendirildi.

BULGULAR: Duyu incelemesinde Grup A’da üç kötü ve bir orta sonuç, Grup B'de iki kötü ve bir orta sonuç elde edildi. İstatististiksel olarak fark saptanmadı. Gruplar arasında cerrahi süre ve toplam floroskopi süresi açısından fark saptanmadı. Medial mini açık yapılan grupta medial pin fiksasyonu sırasında floroskopi süresi daha kısa saptandı.

TARTIŞMA: Medial mini açık teknik ve perkütan tekniğin her ikisin dede iyatrojenik ulnar sinir yaralanma riski mevcuttur. Medial mini açık teknikte medial pin yerleştirme işlemi daha kısa süre floroskopi kullanımı açısından avantajıdır.

Anahtar sözcükler: Humerus; kırık; pediatrik; suprakondiler kırı; ulnar sinir. 